\title{
GREEN HUMAN RESOURCE MANAGEMENT AND GREEN HUMAN CAPITAL: A SYSTEMATIC LITERATURE REVIEW
}

\author{
Muhammad SHOAIB ${ }^{*}$, Roman ZÁMEČNÍK ${ }^{2}$, Zuhair ABBAS ${ }^{3}$, \\ Mohsin JAVED ${ }^{4}$, Asad Ur REHMAN ${ }^{5}$ \\ 1,2,3,4 Department of Business Administration, Faculty of Management and Economics, \\ Tomas Bata University in Zlin, nám. T. G. Masaryka 5555, 76001 Zlín, Czech Republic \\ ${ }^{5}$ University Sultan Zainul Abidin, Kuala Terengganu, Malaysia
}

Received 23 February 2021; accepted 1 April 2021

\begin{abstract}
Purpose - green human resource management (GHRM) and green human capital (GHC) are relatively overlooked aspects in the existing literature of human resource management. Keeping in view, this systematic literature review attempts to highlight and explore its related avenues in the fresh domains of GHRM-GHC and provide a future research agenda for the development of knowledge.

Research methodology - this study employs a systematic literature review methodology. The review analyses 25 studies especially focused on secondary data of peer-reviewed articles published in academic journals from 2008 to 2020.

Findings - this study demonstrated that green HRM is imperative for the implementation of environmental sustainability. More importantly, green human capital is considered an important strategic tool for HR managers and policy makers for devising human resource policies.

Research limitations - this study only focus on articles reported in high-quality research journals. However, other scholarly materials, such as books and conference articles have not been included in the review analyses.

Practical implications - this study provides guidelines to policymakers and managers to pay attention towards environmental sustainability and future research agenda to carry out analytical and empirical research.

Originality/Value - this study enhances the body of knowledge on GHRM field. This study provides a pathway for scholars to explore the emerging areas of human resource management such as green intellectual capital and green human capital to achieve sustainable development and competitive advantage.
\end{abstract}

Keywords: green human resource management, green human capital, systematic quantitative literature review.

JEL Classification: M1, M10, M14.

Conference topic: Contemporary Organizations Development Management.

\section{Introduction}

Green human resource management (GHRM) refers to certain policies, practices, and systems of organizations to make their employees green to protect the natural environment and reap greater benefits at the individual, societal, and business level (Opatha \& Arulrajah, 2014). The contemporary focus makes GHRM study is more in demand by academics (Dumont et al., 2017; Jabbour et al., 2019; Yong et al., 2019). Consequently, recent science has run off the charts and a growing understanding of sustainability concerns has led HR to adopt Green HR activities with a particular emphasis on a paperless solution, reducing the carbon footprint and waste management (Ahmad, 2015). HR helps initiate innovative eco-sustainable programs that include people in the process and initiate improvements to current procedures (Mishra et al., 2014). Green HRM is scheduled, continuing the phase marked by the organizational transition (Sawang \& Kivits, 2014). The supply of green human capital fosters green supply chain management, which involves green manufacturing and reverse logistics to attain sustainability (Lee \& Klassen, 2008; Jabbour et al., 2019).

Most recently, sustainable performance has gained heightened interest, and researchers have started to focus on the partnership between sustainable performance and green human resource management. Zaid et al. (2018) and green

\footnotetext{
"E-mail: shoaib@utb.cz
}

(C) 2021 Authors. Published by Vilnius Gediminas Technical University. This is an open-access article distributed under the terms of the Creative Commons Attribution (http://creativecommons.org/licenses/by/4.0/) License, which permits unrestricted use, distribution, and reproduction in any medium, provided the original author and source are credited. 
human capital (Yusoff et al., 2019). In this period of rivalry, green human resource management and sustainability have gained tremendous interest and emphasis and are seen as a means to build and deploy new human resource competencies (Khandekar \& Sharma, 2005; Ambec \& Lanoie, 2008). Additionally, better energy usage translates into greater efficiency, greater profitability, and further growth and advancement in an enterprise (Jackson et al., 2011). Besides, some core issues also remain of significant concern with respect to the creation and achievement of sustainability targets. The principles, opinions, perceptions, and actions of human capital in the execution of sustainable objectives. Words such as sustainability and greening are increasingly utilized in the business environment, stressing any company to adopt these values in true spirit.

Jabbour and Santos (2008) observed an absence of convergence between human resource aspects and environmental sustainability, i.e., environmental efficiency. Human resources functions promote environmental sustainability changes in an organization. Research in this field will help companies expand their knowledge base and build a greater understanding among managers to effectively execute sustainable human resource management practices (Jabbour \& Santos, 2008). As a result, Chen's (2008) work has become one of the most significant attempts to highlight the role of green intellectual capital (GIC) in achieving competitive advantage. All tangible assets or experiences associated with green innovation or protection are referred to as GIC. Green human capital (GHC), green structural capital (GSC), and green relational capital (GRC) are three types of GIC, both of which have a beneficial impact on a company's competitive edge. GHC applies to workers' environmental competence, understanding, approach, or dedication, and it plays an important role in environmental growth and creativity.

More importantly, it has been suggested that further research to examine the green HRM and green human capital (Shoaib et al., 2021; Abbas et al., 2020). Additionally, Javed and Tučková (2020) also suggested to explore the competitiveness by considering relevant segments through green HRM. Although studies of green HRM are gaining heightened attention, yet the different areas of focus remain quite vague and demand dire attention of researchers and practitioners. Thus, it is important to assemble systematically to enhance the understanding of this structure and briefly examine the current body of Green HRM and Green human capital research. No current literature reviews are investigating and evaluating the growing body of literature on Green HRM and Green human capital. Hence, a systematic and extensive literature review on Green HRM and green human capital needs to be created. The paper presents an in-depth study of Green HRM and green human capital literature reported in high-ranking scholarly journals.

Keeping in view the aforementioned research problems and the presented research gaps, this study has the following research objectives:

- To offer readers a basic understanding and interpretation of green HRM and green human capital.

- To highlight and explore its related avenues in the fresh domains of green human resource management and green human capital to provide future research agenda for the development of knowledge.

- Discuss the different sustainability practices a company should utilize to encourage a greener workplace and explicitly explore the overlooked elements of the GHRM and GHC.

\section{Theoretical development}

\subsection{Green human resource management}

Many scholars have conceptualized the idea of Green HRM and have tested it in diverse environments, and have proposed a computational model to explain Green HRM outcomes for a person and an organization. The role of the literature in making organizational effectiveness relevant is that it is essential to recognize human resource management activities (Hung et al., 2016). The organizational environmental policies and objectives are paired with environmental goals to establish an efficient environmental management strategy. Daily and Huang (2001) suggested that an organization can balance economic growth and environmental protection as it has been tested that in doing so, the organization will profit more than ever (Murari \& Bhandari, 2011). The Human Resource Department plays a crucial function in the production and facilitation of an organization's efficiency (Harmon et al., 2010). The greater the magnitude of green HR regulations, the greater the intensity of EM programs and competitors' policies (Bohdanowicz et al., 2011).

\subsection{Green human capital}

Wright et al. (1994), claimed the competitive edge should be maintained depending on the pool of resources accessible to an organization. Human capital makes up a crucial strategic advantage for sustaining corporate efficiency because workers' expertise and abilities are necessary to support a company in today's competitive world. However, the literature documenting the presence of green human capital is minimal (Yong et al., 2019). Another belief is that educational systems help improve green talent and enhance workers' expertise while helping in the manufacturing processes. Therefore, displaying green human capital can reflect an organization's intangible assets (knowledge, expertise, and capabilities) and allow an organization to apply green strategies in a complex business setting. A company's aims can only be achieved through the dedication of top management, and the top management's position in the implementation of green initiatives is important (Yusliza et al., 2019). 
Focus on rising green human capital availability: managers may prepare the scope of green operations, identify skill gaps, and suggest training programs appropriately. Managers must advertise using the correct green work description, hire qualified candidates who can complete assignments, and maintain talent via reward systems, among other things. Developing a pool of green human capital necessitates an investment in training and growth, but the payoff is substantial. Not only does the business profit from the availability of green human capital, but so do its supply chain partners, such as manufacturers and clients, as greenness pervades all levels in the pursuit of sustainable production and consumption.

It is recommended that staff's expertise and abilities lead to their adaptation to green human resource management techniques (Campbell \& Garmestani, 2012). On the one hand, research has found that expertise and ability grow when workers perceive organizational environmental sustainability, contributing to improving the employee's engagement (Chahal \& Bakshi, 2014). The human resource sector offers a labor management collaboration in which green human resources mediate between green human resource management and employee involvement (Delgado-Verde et al., 2014).

\subsection{Green human resource management practices}

\subsubsection{Green recruitment and selection}

Organizations should recruit people who have the same goals and beliefs (Renwick et al., 2013). Therefore, to recruit more environmentally friendly talent, companies can develop environmental identity and picture that would encourage their workers to take environmentalism seriously (Kapil \& Sharma, 2015; Guerci et al., 2016). Recruitment guarantees that new hires share the organization's green cultural ideals and support its sustainability mission by pointing out their environmental awareness, values, and beliefs (Renwick et al., 2013). Recruitment messages can be made to conform to environmental standards (Arulrajah et al., 2015).

\subsubsection{Green training and development}

Two structures in an entity tend to be interrelated as they grow together. Opatha and Arulrajah (2014) noted that educating employees on environmental awareness is the most important impact towards environmental awareness among employees. The authors argue that this form of preparation contributes to an atmosphere in which sustainability activities are fostered within organizations. According to the scholars, it is important to plan environmental training focused on what the training is supposed to accomplish. The paper recommends such green training and growth strategies such as training employees to create energy-saving work-spaces, to handle waste, to recycle, and to improve green personal skills.

\subsubsection{Green performance management and appraisal}

Organizations must follow corporate-wide metrics monitoring the procurement, utilization, and waste of energy while simultaneously instituting environmental management programs to monitor capital flows and environmental audits (Arulrajah et al., 2015; Jackson \& Seo, 2010). HRM can incorporate environmental goals into performance objectives by setting environmental objectives obligations and measuring environmental success by utilizing green job ranking as the primary performance metrics (Sharma \& Gupta, 2015; Kapil \& Sharma, 2015). Ahmad (2015) argues that managers should change the performance assessment ranking framework to workers depending on their environmental management abilities.

\subsubsection{Green reward and compensation}

Promoting environmentalism in the workplace may be accomplished by boasting incentives for workers' contribution to environmentalism (Jabbour \& Santos, 2008; Jabbour \& de Sousa Jabbour, 2016). Calia et al. (2009) found that to improve workers' ability to make environmentally sustainable choices, incentives could be associated with greening programs in an enterprise. Recognition incentives are essential to the business's growth, and they are open to various degrees within the corporation (Arulrajah et al., 2015). Organizations can use green reward management practices such as connecting promotion to green initiatives or offering rewards to promote eco-friendly practices (Jabbar \& Abid, 2014; Prasad et al., 2013).

\subsubsection{Green employee empowerment and participation}

To render a participative work atmosphere for top managers, HR workers should demonstrate the need to build a participative work environment; where employees can dispute, compromise, and propose new suggestions (Liebowitz, 2010). However, the value of workers' ownership and engagement is reinforced by employees' willingness to make choices about environmental challenges and other concerns that may arise in adopting environmental protection measures (Daily \& Huang, 2001; Daily et al., 2012). With a motivated staff, workers are more willing to invest in environment-related changes (Govindarajulu \& Daily, 2004). 


\subsubsection{Green management of organizational culture}

To create a green culture as a part of HRM practice, training and education are essential (Jabbour \& Santos, 2008; Jabbour \& de Sousa Jabbour, 2016). Sharma and Gupta (2015) proved that GHRM encourages EP in organizations by core principles, and this core drives towards a corporate green culture. With organizational culture recognized as a factor in promoting or inhibiting employee participation and the desire to adopt spiritual environmental behaviors, and employee participation in change initiatives for increasing environmental performance (Rothenberg, 2003; Ones \& Dilchert, 2012; Paillé \& Boiral, 2013; Paillé \& Raineri, 2015). In addition, Gupta and Kumar (2013) have emphasized that staff should be allowed to express their views on how environmental acts should be conducted and implemented to instil a green culture. Members of the company are urged to be open to their green initiatives such that management can be mindful of the programs' sustainability.

From these summarized studies, in Table 1, we can identify that GRHM-related studies were conducted in different industries including both manufacturing and service, and in both developed and developing countries.

\subsection{Green initiatives for Human resources}

Organizations employ HR structures aligned with their overarching philosophy, corporate strategy, and value systems (Boselie et al., 2001). In the long term, the sustainability measures contained in the HRM manifesto are essential to Corporate Social Responsibility. Companies are currently combining sustainability strategies into their agenda, which is supported with the aid of their human resources. Managers make sure that HR team members support sustainable and ethical standards. In conjunction with this, many authors have proposed that many technological and management skills are required to introduce an effective corporate green management scheme, particularly for all company employees (Daily et al., 2009; Unnikrishnan \& Hegde, 2007). There are myriad GHRM issues that HR departments may consider before initiating green programs, and many of them cannot be addressed in a single document. Due to a lack of space, the following section of the paper will touch on a few of the most important green initiatives for HR departments.

There are various GHRM challenges that HR departments must discuss before introducing green policies, and all of them cannot be addressed in a single document. In Table 2, several of the big green initiatives for HR departments are briefly discussed in this paper.

Table 1. Summary of GHRM and GHC-related studies (source: created by authors)

\begin{tabular}{|c|c|c|}
\hline Authors & Context & Major GHRM-related findings \\
\hline $\begin{array}{l}\text { Mousa and } \\
\text { Othman (2020) }\end{array}$ & $\begin{array}{l}\text { ealthcare } \\
\text { ganizations }\end{array}$ & $\begin{array}{l}\text { The researchers described and prioritized numerous green practices. The most influential } \\
\text { practices were green hiring, green recruitment, engagement, green success monitoring, } \\
\text { and compensation; the least influential practices were green waste management and green } \\
\text { buying. }\end{array}$ \\
\hline $\begin{array}{l}\text { Yusliza } \\
(2020)\end{array}$ & turing & $\begin{array}{l}\text { The studies have a variety of educational implications for Green companies and } \\
\text { organizations. This research's significance is that it is the first to explore green intellectual } \\
\text { capital's contribution as an intangible asset that can positively impact businesses and allow } \\
\text { them to attain a sustainable competitive advantage. }\end{array}$ \\
\hline $\begin{array}{l}\text { Zaid a } \\
\text { Jaaron }\end{array}$ & turing & $\begin{array}{l}\text { The statistical study finds that GHRM bundles boost company efficiency in four distinct } \\
\text { ways. This analysis's outcomes can be extended to industrial companies in assisting them in } \\
\text { making sustainable business process improvements. }\end{array}$ \\
\hline $\begin{array}{l}\text { Malik } \\
(2020)\end{array}$ & ring & $\begin{array}{l}\text { The research explained how green HRM activities (green hiring and selection and green } \\
\text { rewards), green intellectual capital (green human capital, green institutional capital, and } \\
\text { green relational capital), and the two aspects of green HRM activities (green recruiting and } \\
\text { selection and green rewards) have a positive effect on a firm's sustainability. Human capital } \\
\text { is central in the Green Human Capital model. }\end{array}$ \\
\hline $\begin{array}{l}\text { Arqawi } \\
(2019)\end{array}$ & cturing & $\begin{array}{l}\text { The findings indicate that there are GHRM procedures applied at certain companies } \\
\text { but not all firms. Directions may be generalized to explore the subject in greater depth. } \\
\text { Academicians and practitioners should use this finding in their study and market plans to } \\
\text { enhance sustainability efficiency and successfully apply GHRM activities. }\end{array}$ \\
\hline $\begin{array}{l}\text { Bag et al. } \\
\text { (2019) }\end{array}$ & $\begin{array}{l}\text { Manuf } \\
\text { firms }\end{array}$ & $\begin{array}{l}\text { Availability of a broad green human capital is positively linked to the implementation and } \\
\text { success of reverse logistics. Sustainability culture has a moderating impact on the pace at } \\
\text { which sustainable supply chains are implemented. The working impact it has on the supply } \\
\text { of green human capital and the efficiency of re-manufacturing operations. }\end{array}$ \\
\hline $\begin{array}{l}\text { Yong et al. } \\
\text { (2019) }\end{array}$ & $\begin{array}{l}\text { anufacturing } \\
\text { ctor. }\end{array}$ & $\begin{array}{l}\text { Surprisingly, green human capital and green institutional capital were debated widely among } \\
\text { the three dimensions of green intellectual capital by human resources administrators. In } \\
\text { contrast, Green relational capital was scarcely considered when Green HRM introduced it. }\end{array}$ \\
\hline $\begin{array}{l}\text { Yong et al. } \\
\text { (2019) }\end{array}$ & $\begin{array}{l}\text { Manufacturing } \\
\text { firms }\end{array}$ & $\begin{array}{l}\text { Results show that investments in green human capital and green relational capital affect } \\
\text { how human resources are handled. The factor of green human resource management was } \\
\text { not substantially connected to green structural capital. }\end{array}$ \\
\hline
\end{tabular}


Table 2. Sustainability practices (source: created by authors)

\begin{tabular}{|l|l|}
\hline \multicolumn{1}{|c|}{ Green initiatives } & \multicolumn{1}{c|}{ Descriptions } \\
\hline Green building & $\begin{array}{l}\text { Organizations all over the world are heading towards greater efficiency and green design as an } \\
\text { alternative to conventional workplaces. Green construction programs have an emphasis on energy } \\
\text { conservation, clean energy, and utilizing storm-water effectively. }\end{array}$ \\
\hline Paperless office & $\begin{array}{l}\text { The bulk of work in the workplace is performed on paper, although it is diminishing with IT's } \\
\text { advent. The new workplace has evolved with the introduction of e-business and, with it, paperless } \\
\text { workplaces. }\end{array}$ \\
\hline $\begin{array}{l}\text { Corporate gardens with } \\
\text { natural fertilizers and } \\
\text { pesticides }\end{array}$ & $\begin{array}{l}\text { All offices can preserve garden areas and greening of landscaped grounds. There should be HR } \\
\text { policies for workers' involvement in planting, such as how to spread compost or what parts of the } \\
\text { field get fertilized. }\end{array}$ \\
\hline $\begin{array}{l}\text { Rewarding the employees } \\
\text { who uses bicycles to } \\
\text { commute or car pools }\end{array}$ & $\begin{array}{l}\text { It would allow residents to travel to work by bicycle or on foot, mitigating noise. Many that reside } \\
\text { far from the market may use bicycles to ride to it. This aerobic workout will help the employee } \\
\text { sustain a healthier lifestyle. }\end{array}$ \\
\hline Conservation of energy & $\begin{array}{l}\text { The inefficiency of the office space improvements is having an environmental effect. Throughout } \\
\text { the region, office buildings are introducing energy efficiency measures to reduce the community's } \\
\text { environmental effect. }\end{array}$ \\
\hline Green rewards & $\begin{array}{l}\text { Rewards would be given to departments and people for creative projects and achievements by } \\
\text { energy efficiency and renewable resources usage. }\end{array}$ \\
\hline $\begin{array}{l}\text { Recycling and waste } \\
\text { disposal }\end{array}$ & $\begin{array}{l}\text { Recycling is the idea of reusing products instead of recycling them. Recycling decreases the use } \\
\text { of natural products contributing to less loss of energy. As a part of this activity, it simultaneously } \\
\text { saves resources and decreases the volume of garbage, thus cleaning up the atmosphere and } \\
\text { keeping the air fresher. }\end{array}$ \\
\hline
\end{tabular}

\section{Research methodology}

This review has considered 25 studies published over 12 years between 2008 and 2020 by using Web of Science and Scopus databases - aiming to cover studies related to the GHRM and green human capital. In conjunction with Moher et al. (2010), these findings were performed with a standard form of systematic analysis. Many relevant papers have proposed that a certain minimum number of specific publications be included in systematic reviews (Junior \& Godinho Filho, 2010; Van Kampen et al., 2012). The mathematical study was done in Excel to address the research query. The keywords were used to find the normally listed research in the abstract and titles of papers. Paper searches' main phrases are "green human resource management" and "green human capital." The graphical figure below illustrates how publications are found by searching the literature.

The above Figure 1 indicates that this study found only 79 studies published in the Web of Science database on the GHRM and Green human capital. While we analyzed only 52 studies which were relevant to GHRM and green human capital. However, we followed the inclusion and exclusion criteria and found 27 studies. Finally, after the constructive review of 27 articles, we selected only 25 studies which are related to our objectives and questions.

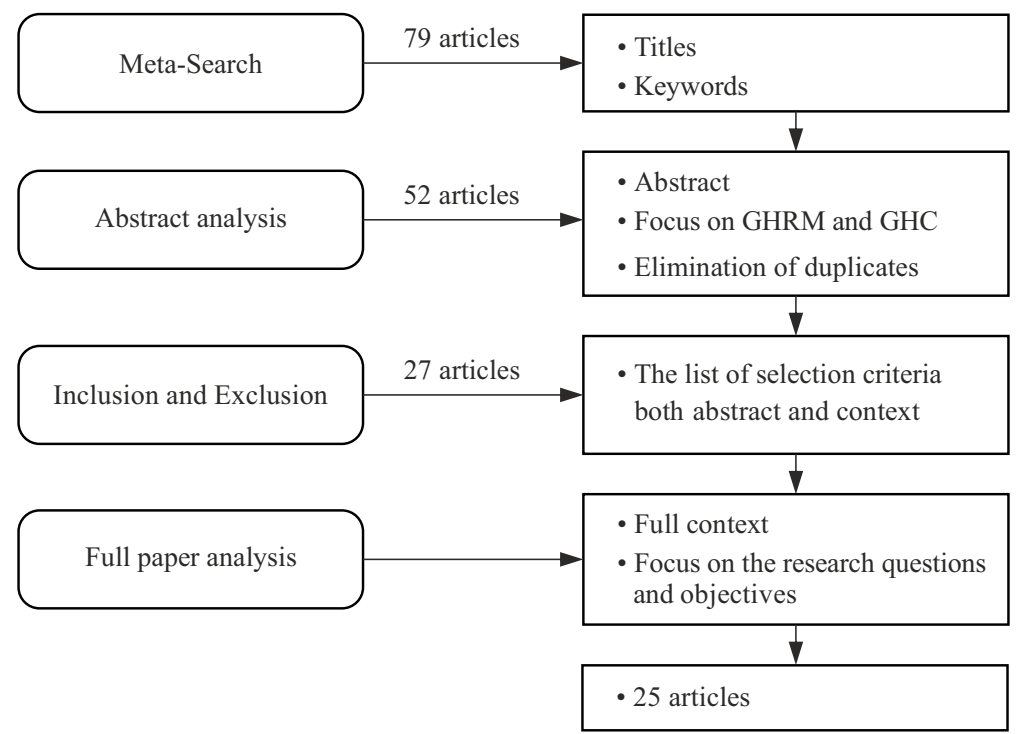

Figure 1. Systematic literature search by using PRISMA (source: created by authors) 


\section{Results}

Table 3 shows that most of the 214 GHRM studies published in the SCOPUS database and 171 studies published in Web of Science database. While limited research was conducted on Green human capital with 24 studies in SCOPUS and 19 studies in Web of Science database. On the other hand, 109 studies published in SCOPUS and 79 studies in Web of Science.

Table 4 shows that highly cited scholar in the field of GHRM is Douglas W. S. Renwick. His contribution is novel for existing literature and he is a role model for other scholars too. While, Pascal Paille also played his great role in green human resource management towards environmental performance especially at employee level in the literature. Additionally, Chiappetta Jabbour Charbel Jose is also great research scholar. Finally, Jenny Dumont and Yong Joong Kim are also providing encouragement to early researchers in this field.

Table 5 indicates that Douglas W. S. Renwick is highly cited research scholar in the field of green human capital. On the other hand, Jing Yi Yong is also an emerging scholar in the green intellectual capital field. Figure 2 shows that the literature for 2008 compared to HRM (e.g., Unnikrishnan \& Hegde, 2007). However, for a while, in the conception of Green Human Resources Management and green human capital, there were just a limited amount of electronic publications (between 2008 and 2015). More recently, due to the rise of environmental issues concepts, GHRM has focused on environmental sustainability and Green Human capital. According to Figure 2, research attention has increased and stable with time from 2016. A large number of conceptual and empirical studies have been undertaken to hone the Green HRM and green human capital concept, and this philosophy has been widely adopted within the industry. An empirical field with long-focused emphasis on this subject may be attributable to the value of GHRM and green human capital.

\section{Discussion}

This study demonstrates a link between green human resource management (GHRM) and green human capital. More importantly, this study highlighted and explored fresh domains of GHRM and GHC, such as green transformational leadership, green work-life balance, green intrinsic motivation, green extrinsic motivation, and green work engagement. Additionally, this review also revealed green intellectual capital with sustainability employee personality traits; green relational capital, green training can be viewed as interesting avenues for future research to get a better understanding.

Table 3. Results of own literature review in the field (source: created by authors)

\begin{tabular}{|l|c|c|}
\hline \multicolumn{1}{|c|}{ Keywords } & SCOPUS & WoS \\
\hline Green HRM and Green human capital & 109 & 79 \\
\hline Green HRM & 214 & 171 \\
\hline Green Human capital & 24 & 19 \\
\hline
\end{tabular}

Table 4. Top cited authors in GHRM field (source: created by authors)

\begin{tabular}{|l|l|c|}
\hline \multicolumn{1}{|c|}{ Author } & \multicolumn{1}{|c|}{ Title } & Citations \\
\hline Douglas W. S. Renwick & Green human resource management: a review and research agenda & 341 \\
\hline Pascal Paille & $\begin{array}{l}\text { The impact of human resource management on environmental performance: } \\
\text { an employee-level study }\end{array}$ & 182 \\
\hline $\begin{array}{l}\text { Chiappetta Jabbour } \\
\text { Charbel Jose }\end{array}$ & $\begin{array}{l}\text { Green human resource management and green supply chain management: } \\
\text { linking two emerging agendas }\end{array}$ & 114 \\
\hline Jenny Dumont & $\begin{array}{l}\text { Effects of Green HRM practices on employee workplace green behavior: the } \\
\text { role of psychological green climate and employee green values }\end{array}$ & 90 \\
\hline Yong Joong Kim & $\begin{array}{l}\text { The effect of green human resource management on hotel employees' eco- } \\
\text { friendly behavior and environmental performance }\end{array}$ & \\
\hline
\end{tabular}

Table 5. Top cited authors in green human capital (source: created by authors)

\begin{tabular}{|l|l|c|}
\hline \multicolumn{1}{|c|}{ Author } & \multicolumn{1}{|c|}{ Title } & Citations \\
\hline Douglas W. S. Renwick & The positive effect of green intellectual capital on competitive advantage of firms & 188 \\
\hline Ching-Hsun Chang & The determinants of green intellectual capital & 47 \\
\hline Ching-Hsun Chang & The determinants of green product innovation performance & 35 \\
\hline Jing Yi Yong & Nexus between green intellectual capital and green human resource management & 31 \\
\hline
\end{tabular}




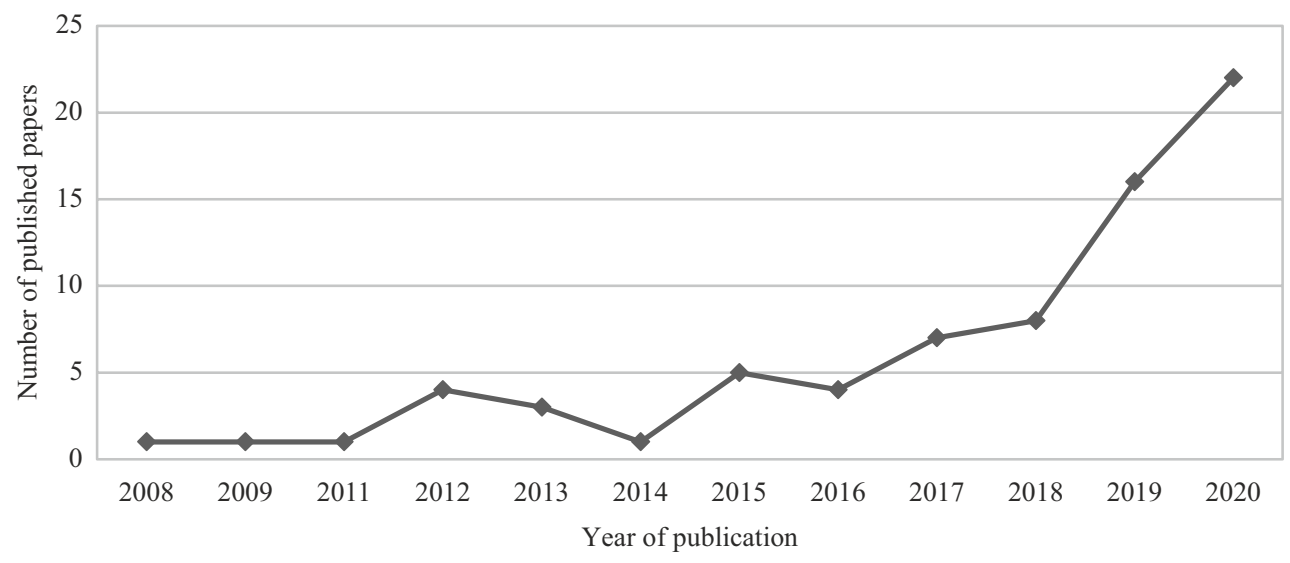

Figure 2. Trend analysis number of articles published in year wise on Green Human Resource Management and Green human capital (source: created by authors)

This review also found that technological sustainability, environmental sustainability, and social sustainability are overlooked and can be used for further research to launch green practices at the workplace. This study brings new insights such as green HRM and green human capital can be explored with industry 4.0 for the transformation of businesses sustainability. Recently, policymakers, leaders and managers were concerned about sustainability practices at the workplace for conservation of resources, preservation of environment, and take care of employee well-being. A business paradigm is shifting from profit maximization towards all stakeholders by achieving not only economic performance but also environmental and social performance for fulfil Sustainable development goals (SDGs) under the vision of United Nations.

This review of reputable literature from 2008 to 2020 demonstrates the significance of Green HRM and green human capital in securing environmental sustainability and productivity in today's business world through systemic and individual participation. Because Green HRM and Green human capital are comparatively new concepts, other academics have conceptualized them, tested them in multiple settings, and recommended a conceptual model to interpret the results of Green HRM and Green human capital implementation for an individual and an organization. Sustainability and global growth are among the most challenging problems facing all government, professional, and existing institutions (Olawumi \& Chan, 2018). Green human resources approaches, such as green recruiting, green training (Pinzone et al., 2019), and green incentives, are not only conducive to enhancing environmental achievement but also to the creation of green human capital, assisting in the improvement of everyday behaviour among workers and hence the work culture. Green human resource management is a driving force behind workplace environmental sustainability.

\section{Conclusions}

The research papers written between 2008 and 2020 were searched and systematically evaluated. The material on Green HRM and the literature on green human capital are illustrated in terms of its conceptualization, application, determinants, and results in both organizational and individual contexts. This trend study suggests that green human resources and green human capital would accelerate due to global policymakers and leaders' and managers' involvement in environmental concerns and climate change. Scholars are worried about this contemporary problem and an evolving areas to apply sustainability practices to neutralize environmental concerns and reduce organizations' costs. Additionally, the results offer more evidence on the understandings of green HRM dimensions and how various scholars conceptualize green HRM. Green HRM activities and green human capital are essential for businesses in the current market world. Therefore, decision-makers and top managers must provide a comprehensive and full view of it to utilize it effectively in the best interest of society and the world. This study only focuses on articles reported in high-quality research journals. However, other scholarly materials, such as books and conference articles have not been included in the review analyses. Furthermore, this study provides guidelines to policymakers and managers to pay attention towards sustainability.

\section{Future research agenda}

This review provides a future research agenda for further research to the body of knowledge on the human resource management field. This study found these important explored areas for further research such as organization green culture, role of union in environmental management, organization learning, green health and safety, green employee 
performance, green attitudes, top management commitment for greening the workforce, employee satisfaction, green intellectual capital with circular economy, green human capital with corporate sustainability, knowledge management practices for sustainability via mediation mechanism of green human capital.

\section{Funding}

The authors are thankful and acknowledge to the Internal Grant Agency of FaME TBU No. IGA/FaME/2021/009, project title: "Green Human Resource Management Practices Leading Transformation towards Sustainable Performance in the Selected Sectors" and IGA/FaME/2020/010, project title: "The Measurement of Performance in Selected Sectors with The Emphasis on Human Resources Indicators" for providing financial support to carrying out this research.

\section{Contribution}

Conceptualization: Muhammad SHOAIB, Roman ZÁMEČNÍK.

Formal Analysis: Zuhair ABBAS.

Methodology: Mohsin JAVED.

Validation: Asad Ur REHMAN.

Funding Acquisition: Muhammad SHOAIB, Roman ZÁMEČNÍK, Zuhair ABBAS.

Writing - original draft: Muhammad SHOAIB, Roman ZÁMEČNÍK, Zuhair ABBAS, Mohsin JAVED, Asad Ur REHMAN.

Writing - review \& editing: Muhammad SHOAIB, Roman ZÁMEČNÍK, Zuhair ABBAS, Mohsin JAVED, Asad Ur REHMAN.

\section{Disclosure statement}

On behalf of all authors, the corresponding author states that there is no conflict of interest whatsoever.

\section{References}

Abbas, Z., Shoaib, M., Zlámalová, J., \& Zámečník, R. (2020). Green human resource management as a way to support sustainability: a literature review. In DOKBAT 2020 Conference Proceedings - 16th Annual International Bata Conference for PhD Students and Young Researchers, (Vol. 16, p. 9). Tomas Bata University in Zlín, Faculty of Management and Economics. https://doi.org/10.7441/dokbat.2020.01

Ahmad, S. (2015). Green human resource management: Policies and practices. Cogent Business \& Management, 2(1), 1030817. https://doi.org/10.1080/23311975.2015.1030817

Ambec, S., \& Lanoie, P. (2008). Does it pay to be green? A systematic overview. Academy of Management Perspectives, 22(4), 45-62. https://doi.org/10.5465/amp.2008.35590353

Arqawi, S., Zaid, A. A., Jaaron, A. A., Al Hila, A. A., Al Shobaki, M. J., \& Abu-Naser, S. S. (2019). Green human resource management practices among Palestinian manufacturing firms-an exploratory study. Journal of Resources Development and Management, 52. https://doi.org/10.7176/JRDM

Arulrajah, A., Disfani, M. M., Maghoolpilehrood, F., Horpibulsuk, S., Udonchai, A., Imteaz, M., \& Du, Y. J. (2015). Engineering and environmental properties of foamed recycled glass as a lightweight engineering material. Journal of Cleaner Production, 94, 369-375. https://doi.org/10.1016/j.jclepro.2015.01.080

Bag, S., Gupta, S., \& Foropon, C. (2019). Examining the role of dynamic remanufacturing capability on supply chain resilience in circular economy. Management Decision, 57(4), 863-885. https://doi.org/10.1108/MD-07-2018-0724

Bohdanowicz, P., Zientara, P., \& Novotna, E. (2011). International hotel chains and environmental protection: an analysis of Hilton's we care! programme (Europe, 2006-2008). Journal of Sustainable Tourism, 19(7), 797-816. https://doi.org/10.1080/09669582.2010.549566

Boselie, P., Paauwe, J., \& Jansen, P. (2001). Human resource management and performance: lessons from the Netherlands. International Journal of Human Resource Management, 12(7), 1107-1125. https://doi.org/10.1080/09585190110068331

Campbell, D. E., \& Garmestani, A. S. (2012). An energy system view of sustainability: emergy evaluation of the San Luis Basin, Colorado. Journal of Environmental Management, 95(1), 72-97. https://doi.org/10.1016/j.jenvman.2011.07.028

Calia, R. C., Guerrini, F. M., \& de Castro, M. (2009). The impact of Six Sigma in the performance of a Pollution Prevention program. Journal of Cleaner Production, 17(15), 1303-1310. https://doi.org/10.1016/j.jclepro.2009.05.001

Chahal, H., \& Bakshi, P. (2014). Effect of intellectual capital on competitive advantage and business performance: Role of innovation and learning culture. International Journal of Learning and Intellectual Capital, 11(1), 52-70. https://doi.org/10.1504/IJLIC.2014.059227

Chang, C. H. (2016). The determinants of green product innovation performance. Corporate Social Responsibility and Environmental Management, 23(2), 65-76. https://doi.org/10.1002/csr.1361 
Chen, Y. S. (2008). The positive effect of green intellectual capital on competitive advantages of firms. Journal of Business Ethics, 77(3), 271-286. https://doi.org/10.1007/s10551-006-9349-1

Daily, B. F., \& Huang, S. C. (2001). Achieving sustainability through attention to human resource factors in environmental management. International Journal of Operations \& Production Management, 21(12), 1539-1552. https://doi.org/10.1108/01443570110410892

Daily, B. F., Bishop, J. W., \& Massoud, J. A. (2012). The role of training and empowerment in environmental performance. International Journal of Operations \& Production Management, 32(5), 631-647. https://doi.org/10.1108/01443571211226524

Daily, B. F., Bishop, J. W., \& Govindarajulu, N. (2009). A conceptual model for organizational citizenship behavior directed toward the environment. Business \& Society, 48(2), 243-256. https://doi.org/10.1177/0007650308315439

Delgado-Verde, M., Amores-Salvadó, J., Martín-de Castro, G., \& Navas-López, J. E. (2014). Green intellectual capital and environmental product innovation: the mediating role of green social capital. Knowledge Management Research \& Practice, 12(3), 261-275. https://doi.org/10.1057/kmrp.2014.8

Dumont, J., Shen, J., \& Deng, X. (2017). Effects of green HRM practices on employee workplace green behavior: The role of psychological green climate and employee green values. Human Resource Management, 56(4), 613-627. https://doi.org/10.1002/hrm.21792

Govindarajulu, N., \& Daily, B. F. (2004). Motivating employees for environmental improvement. Industrial Management \& Data Systems, 104(4), 364-372. https://doi.org/10.1108/02635570410530775

Guerci, M., Longoni, A., \& Luzzini, D. (2016). Translating stakeholder pressures into environmental performance - the mediating role of green HRM practices. The International Journal of Human Resource Management, 27(2), 262-289. https://doi.org/10.1080/09585192.2015.1065431

Gupta, S., \& Kumar, V. (2013). Sustainability as corporate culture of a brand for superior performance. Journal of World Business, 48(3), 311-320. https://doi.org/10.1016/j.jwb.2012.07.015

Harmon, J., Fairfield, K. D., \& Wirtenberg, J. (2010). Missing an opportunity: HR leadership and sustainability. People and Strategy, 33(1), 16.

Hung, Y. T., Cant, M. C., \& Wiid, J. A. (2016). The importance of human resources management for small businesses in South Africa. Problems and Perspectives in Management, 14(3-1), 232-238. https://doi.org/10.21511/ppm.14(3-1).2016.09

Jabbar, M. H., \& Abid, M. (2014). GHRM: Motivating employees towards organizational environmental performance. MAGNT Research Report, 2(4), 267-278.

Jabbour, C. J. C., \& de Sousa Jabbour, A. B. L. (2016). Green human resource management and green supply chain management: Linking two emerging agendas. Journal of Cleaner Production, 112(Part 3), 1824-1833. https://doi.org/10.1016/j.jclepro.2015.01.052

Jabbour, C. J. C., \& Santos, F. C. A. (2008). The central role of human resource management in the search for sustainable organizations. The International Journal of Human Resource Management, 19(12), 2133-2154. https://doi.org/10.1080/09585190802479389

Jabbour, C. J. C., Sarkis, J., de Sousa Jabbour, A. B. L., Renwick, D. W. S., Singh, S. K., Grebinevych, O., Kruglianskas, I. \& Godinho Filho, M. (2019). Who is in charge? A review and a research agenda on the 'human side' of the circular economy. Journal of Cleaner Production, 222, 793-801. https://doi.org/10.1016/j.jclepro.2019.03.038

Jackson, S. E., \& Seo, J. (2010). The greening of strategic HRM scholarship. Organization Management Journal, 7(4), $278-290$. https://doi.org/10.1057/omj.2010.37

Jackson, S. E., Renwick, D. W., Jabbour, C. J., \& Muller-Camen, M. (2011). State-of-the-art and future directions for green human resource management: Introduction to the special issue. German Journal of Human Resource Management, 25(2), 99-116. https://doi.org/10.1177/239700221102500203

Junior, M. L., \& Godinho Filho, M. (2010). Variations of the kanban system: Literature review and classification. International Journal of Production Economics, 125(1), 13-21. https://doi.org/10.1016/j.ijpe.2010.01.009

Javed, M., \& Tučková, Z. (2020). The role of government in tourism competitiveness and tourism area life cycle model. Asia Pacific Journal of Tourism Research, 25(9), 997-1011. https://doi.org/10.1080/10941665.2020.1819836

Kapil, A., \& Sharma, A. (2015). Magnetic pulse welding: an efficient and environmentally friendly multi-material joining technique. Journal of Cleaner Production, 100, 35-58. https://doi.org/10.1016/j.jclepro.2015.03.042

Khandekar, A., \& Sharma, A. (2005). Managing human resource capabilities for sustainable competitive advantage: An empirical analysis from Indian global organisations. Education+Training, 47(8-9), 628-639. https://doi.org/10.1108/00400910510633161

Lee, S. Y., \& Klassen, R. D. (2008). Drivers and enablers that foster environmental management capabilities in small-and mediumsized suppliers in supply chains. Production and Operations Management, 17(6), 573-586. https://doi.org/10.3401/poms.1080.0063

Liebowitz, J. (2010). The role of HR in achieving a sustainability culture. Journal of Sustainable Development, 3(4), $50-57$. https://doi.org/10.5539/jsd.v3n4p50

Malik, S. Y., Cao, Y., Mughal, Y. H., Kundi, G. M., Mughal, M. H., \& Ramayah, T. (2020). Pathways towards sustainability in organizations: Empirical evidence on the role of green human resource management practices and green intellectual capital. Sustainability, 12(8), 3228. https://doi.org/10.3390/su12083228

Mishra, R. K., Sarkar, S., \& Kiranmai, J. (2014). Green HRM: innovative approach in Indian public enterprises. World Review of Science, Technology and Sustainable Development, 11(1), 26-42. https://doi.org/10.1504/WRSTSD.2014.062374

Moher, D., Liberati, A., Tetzlaff, J., \& Altman, D. G. (2010). Preferred reporting items for systematic reviews and meta-analyses: the PRISMA statement. International Journal of Surgery, 8(5), 336-341. https://doi.org/10.1016/j.ijsu.2010.02.007 
Mousa, S. K., \& Othman, M. (2020). The impact of green human resource management practices on sustainable performance in healthcare organisations: A conceptual framework. Journal of Cleaner Production, 243, 118595.

https://doi.org/10.1016/j.jclepro.2019.118595

Murari, K., \& Bhandari, M. (2011). Green HR: Going green with pride. Journal of Social Welfare \& Management, 3(3-4), 35-38.

Olawumi, T. O., \& Chan, D. W. (2018). A scientometric review of global research on sustainability and sustainable development. Journal of Cleaner Production, 183, 231-250. https://doi.org/10.1016/j.jclepro.2018.02.162

Ones, D. S., \& Dilchert, S. (2012). Employee green behaviors. The SIOP professional practice series. In Managing human resources for environmental sustainability (pp. 85-116). Jossey-Bass/Wiley.

Opatha, H. H. P., \& Arulrajah, A. A. (2014). Green human resource management: Simplified general reflections. International Business Research, 7(8), 101. https://doi.org/10.5539/ibr.v7n8p101

Paillé, P., \& Boiral, O. (2013). Pro-environmental behavior at work: Construct validity and determinants. Journal of Environmental Psychology, 36, 118-128. https://doi.org/10.1016/j.jenvp.2013.07.014

Paillé, P., \& Raineri, N. (2015). Linking perceived corporate environmental policies and employees' eco-initiatives: The influence of perceived organizational support and psychological contract breach. Journal of Business Research, 68(11), $2404-2411$. https://doi.org/10.1016/j.jbusres.2015.02.021

Pinzone, M., Guerci, M., Lettieri, E., \& Huisingh, D. (2019). Effects of 'green' training on pro-environmental behaviors and job satisfaction: evidence from the Italian healthcare sector. Journal of Cleaner Production, 226, 221-232. https://doi.org/10.1016/j.jclepro.2019.04.048

Prasad, D., Preetam, A., \& Nath, M. (2013). L-Proline-accelerated, eco-friendly synthesis of 9-substituted-2, 3, 4, 9-tetrahydro-1Hxanthen-1-ones under mild conditions. Comptes Rendus Chimie, 16(12), 1153-1157. https://doi.org/10.1016/j.crci.2013.05.011

Renwick, D. W., Redman, T., \& Maguire, S. (2013). Green human resource management: A review and research agenda. International Journal of Management Reviews, 15(1), 1-14. https://doi.org/10.1111/j.1468-2370.2011.00328.x

Rothenberg, S. (2003). Knowledge content and worker participation in environmental management at NUMMI. Journal of Management Studies, 40(7), 1783-1802. https://doi.org/10.1111/1467-6486.00400

Sawang, S., \& Kivits, R. A. (2014). Greener workplace: understanding senior management's adoption decisions through the Theory of Planned Behaviour. Australasian Journal of Environmental Management, 21(1), 22-36. https://doi.org/10.1080/14486563.2013.848418

Sharma, R., \& Gupta, N. (2015, January). Green HRM: An innovative approach to environmental sustainability. In Proceeding of the Twelfth AIMS International Conference on Management (pp. 2-5). Twelfth AIMS.

Shoaib, M., Abbas, Z., Yousaf, M., Zámečník, R., Ahmed, J., \& Saqib, S. (2021). The role of GHRM practices towards organizational commitment: A mediation analysis of green human capital. Cogent Business \& Management, 8(1), 1870798. https://doi.org/10.1080/23311975.2020.1870798

Unnikrishnan, S., \& Hegde, D. S. (2007). Environmental training and cleaner production in Indian industry - A micro-level study. Resources, Conservation and Recycling, 50(4), 427-441. https://doi.org/10.1016/j.resconrec.2006.07.003

Van Kampen, T. J., Akkerman, R., \& van Donk, D. P. (2012). SKU classification: a literature review and conceptual framework. International Journal of Operations \& Production Management, 32(7). https://doi.org/10.1108/01443571211250112

Wright, P. M., McMahan, G. C., \& McWilliams, A. (1994). Human resources and sustained competitive advantage: a resource-based perspective. International Journal of Human Resource Management, 5(2), 301-326. https://doi.org/10.1080/09585199400000020

Yong, J. Y., Yusliza, M. Y., \& Fawehinmi, O. O. (2019). Green human resource management: A systematic literature review from 2007 to 2019. Benchmarking: An International Journal, 27(7), 2005-2027. https://doi.org/10.1108/BIJ-12-2018-0438

Yusliza, M. Y., Norazmi, N. A., Jabbour, C. J. C., Fernando, Y., Fawehinmi, O., \& Seles, B. M. R. P. (2019). Top management commitment, corporate social responsibility and green human resource management. Benchmarking: An International Journal, 26(6), 2051-2078. https://doi.org/10.1108/BIJ-09-2018-0283

Yusliza, M. Y., Yong, J. Y., Tanveer, M. I., Ramayah, T., Faezah, J. N., \& Muhammad, Z. (2020). A structural model of the impact of green intellectual capital on sustainable performance. Journal of Cleaner Production, 249, 119334. https://doi.org/10.1016/j.jclepro.2019.119334

Yusoff, Y. M., Omar, M. K., Zaman, M. D. K., \& Samad, S. (2019). Do all elements of green intellectual capital contribute toward business sustainability? Evidence from the Malaysian context using the Partial Least Squares method. Journal of Cleaner Production, 234, 626-637. https://doi.org/10.1016/j.jclepro.2019.06.153

Zaid, A. A., \& Jaaron, A. A. (2020, 10-12 March). Green human resource management bundle practices and sustainable manufacturing performance: understanding potential relationships [Conference presentation]. International Conference on Industrial Engineering and Operations Management. Dubai, UAE.

Zaid, A. A., Jaaron, A. A., \& Bon, A. T. (2018). The impact of green human resource management and green supply chain management practices on sustainable performance: An empirical study. Journal of Cleaner Production, 204, 965-979.

https://doi.org/10.1016/j.jclepro.2018.09.062 